\title{
Neuromodulatory Approaches to the Treatment of Trigeminal Autonomic Cephalalgias (TACs)
}

\author{
P.J. Goadsby
}

\section{Introduction}

Trigeminal Autonomic Cephalalgias (TACs) is a grouping of headache syndromes including cluster headache, paroxysmal hemicrania and short-lasting unilateral neuralgiform headache attacks with conjunctival injection and tearing (SUNCT) [1]. These syndromes share two major clinical pictures: trigeminal distribution of pain and ipsilateral cranial autonomic symptoms [2]. These features are consistent with cranial parasympathetic activation and sympathetic hypofunction (ptosis and miosis) representing a neurapraxic effect of carotid swelling with cranial parasympathetic activation $[3,4]$. The distinction between TACs and other headache syndromes is the degree of cranial autonomic activation, not its presence alone, since other primary or secondary headaches show this type of activation [5-8].

Positron emission tomography (PET) studies in cluster headache and paroxysmal hemicrania and functional magnetic resonance imaging (MRI) studies in SUNCT have demonstrated ipsilateral posterior hypothalamic activation which seems to be specific to these syndromes and not present in other types of migraine. There are direct hypothalamic-trigeminal connections [9] and the hypothalamus is known to have a modulatory role on the nociceptive and autonomic pathways, specifically trigeminovascular nociceptive pathways [10].

\section{Summary of Background Data and State of Today's Knowledge}

\section{Cluster Headache $(\mathrm{CH})$}

$\mathrm{A} \mathrm{CH}$ attack is an individual episode of pain that can last from a few minutes to some hours. A cluster bout or period usually lasts from some weeks to months. Pain is excruciatingly severe and is mainly located around the orbital and temporal regions and usually lasts 45 to $90 \mathrm{~min}$, with an abrupt onset and cessation. The distinctive feature of $\mathrm{CH}$ is the association with autonomic symptoms such as conjunctival injection, lacrimation, miosis, ptosis, eyelid edema, rhinorrhoea, nasal blockage, forehead or facial sweating. In contrast to migraine, $\mathrm{CH}$ sufferers are usually restless and irritable, move about and look for a movement or posture that may relieve the pain. Alcohol, nitroglycerin, exercise and elevated environmental temperature are precipitants of acute attacks. Most patients have 1 or 2 annual cluster periods, each lasting between 1 and 3 months. It is a lifelong disorder in the majority of patients.

Pharmacological Treatment. Abortive agents are administered parenterally or by the nasal route. They are represented by sumatriptan, zolmitriptan, oxygen inhalation, intranasal dihydroergotamine and subcuta- 
neous octreotide [11-16]. For prevention of attacks, the main stay treatments are high-dose verapamil [17, 18], lithium [19], methysergide [20], melatonin [21], prednisolone [22] and topiramate [23]. Nerve blocks by means of the local injection of anesthetics and corticoids around the greater occipital nerve has yielded inconsistent results [24-26].

Surgery. Destructive procedures may be employed as a last-resort measure in patients resistant to pharmacological treatment and exclusively with unilateral headache. The main procedures employed are the interruption of the trigeminal sensory or autonomic pathways, trigeminal sensory rhizotomy via a posterior fossa approach, radiofrequency trigeminal gangliorhizolysis and microvascular decompression of the trigeminal nerve with or without microvascular decompression of the nervus intermedius. All these techniques bring with them several complications.

Neuromodulation. Franzini et al. [27] and Leone et al. [28] reported favorable lasting results in a cohort of patients with chronic $\mathrm{CH}$ treated with deep brain stimulation (DBS). Suboccipital nerve stimulation is also being investigated in $\mathrm{CH}[28,29]$.

\section{SUNCT}

SUNCT syndrome manifests as a unilateral headache which occurs in association with cranial autonomic features. In contrast to other TACs, attacks have a very brief duration, can occur very frequently and the prominent feature is represented by conjunctival injection and lacrimation [30,31]. This syndrome is rare, has a male predominance (sex ratio: 2.1:1) and the onset is between 40 and 70 years. Pain is usually maximal in the ophthalmic distribution of the trigeminal nerve (orbital and peri-orbital regions, forehead and temple) and is typically unilateral. It is of moderate to severe intensity and attacks last between 5 and 250 seconds [32] although attacks lasting up to 2 hours have been described [33-35]. Attacks are always accompanied by ipsilateral conjunctival injection and lacrimation, while other autonomic symptoms are less commonly reported.

The majority of patients can precipitate attacks by touching trigger zones innervated by trigeminal nerve. SUNCT must be differentiated from trigeminal neuralgia, primary (idiopathic) stabbing headache and paroxysmal hemicrania.

Pharmacological Treatment. Several categories of drugs used in other headache syndromes such as non- steroidal anti-inflammatory drugs (including indomethacin), paracetamol, 5-HT agonists (triptans, ergotamine and dihydroergotamine) beta-adrenergic blockers, tricyclic antidepressants, Ca-channel blockers (verapamil, nifedipine), methysergide, lithium, prednisolone, phenytoin, baclofen and i.v. lignocaine have proved to be ineffective in SUNCT [34]. Intravenous lignocaine has been shown to be effective in the acute suppression of SUNCT [37].

Prevention of attacks may be obtained with carbamazepine [33, 34, 36, 38, 39], lamotrigine [40-44], gabapentin [45-47] and topiramate [34].

Surgery. Several surgical approaches have been tried in SUNCT syndrome, but none has a follow up sufficient to reach reliable conclusions. Destructive procedures are therefore at the moment not recommended.

Neuromodulation. Leone et al. [48] have recently reported excellent results in SUNCT after stimulation of posterior hypothalamus.

\section{Future Directions}

Neuromodulation appears to be a promising new approach to treatment of both $\mathrm{CH}$ and SUNCT syndromes refractory to other treatments.

\section{References}

1. Headache Classification Committee of The International Headache Society. The International Classification of Headache Disorders (2nd edn). Cephalalgia 2004; 24 (Suppl 1):1-160

2. Goadsby PJ, Lipton RB. A review of paroxysmal hemicranias, SUNCT syndrome and other short-lasting headaches with autonomic features, including new cases. Brain 1997; 120: 193-209

3. Ekbom K, Greitz T.Carotid angiography in cluster headache. Acta Radiologica 1970; 10: 177-186

4. May A, Buchel C, Bahra A, Goadsby PJ, Frackowiak RSJ. Intracranial vessels in trigeminal transmitted pain: a PET Study. Neuroimage 1999; 9: 453-460

5. Barbanti P, Fabbrini G, Pesare M, Vanacore N, Cerbo R. Unilateral cranial autonomic symptoms in migraine. Cephalalgia 2002; 22: 256-259

6. Benoliel R, Sharav Y. Trigeminal neuralgia with lacrimation or SUNCT syndrome? Cephalalgia 1998; 18: 85-90

7. Goadsby PJ, Edvinsson L, Ekman R. Cutaneous stimulation leading to facial flushing and release of calcitonin generelated peptide. Cephalalgia 1992; 12:53-56

8. Goadsby PJ, Matharu MS, Boes CJ. SUNCT syndrome or trigeminal neuralgia with lacrimation. Cephalalgia 2001; 21: $82-83$ 
9. Malick A, Burstein R. Cells of origin of the trigeminohypothalamic tract in the rat.J Comp Neurol 1998;400:125-144

10. Bartsch T, Levy MJ, Knight YE, Goadsby PJ. Differential modulation of nociceptive dural input to [hypocretin] Orexin A and B receptor activation in the posterior hypothalamic area. Pain 2004; 109:367-378

11. Ekbom K, The Sumatriptan Cluster Headache Study Group. Treatment of acute cluster headache with sumatriptan. $\mathrm{N}$ Engl J Med 1991; 325:322-326

12. Cittadini E, May A, Straube A et al.Zolmitriptan nasal spray is effective and well tolerated in the acute treatment of cluster headache: a double-blind placebo-controlled crossover study. Europ J Neurology 2005 (in press)

13. Fogan L. Treatment of cluster headache: a double blind comparison of oxygen vs air inhalation. Arch Neurology 1985; 42: 362-363

14. Kitrelle JP, Grouse DS, Seybold ME. Cluster headache: Iocal anesthetic abortive agents. Arch Neurology 1985; 42: 496-498

15. Andersson PG, Jespersen LT. Dihydroergotamine nasal spray in the treatment of attacks of cluster headache. Cephalalgia 1986; 6: 51-54

16. Matharu MS, Levy MJ, Meeran K, Goadsby PJ. Subcutaneous octreotide in cluster headache-randomized placebo-controlled double-blind cross-over study. Ann Neurology 2004; 56: 488-494

17. Lance JW, Goadsby PJ. Mechanism and Management of Headache, 7th edn. New York: Elsevier, 2005

18. Krabbe A, Steiner TJ. Prophylactic treatment of cluster headache. In: Sjaastad O, Nappi G, eds. Cluster headache syndrome in general practice: Basic concepts. London: Smith-Gordon, 2000, pp 91-96

19. Ekbom K, Solomon S. Management of cluster headache. In: Olesen J,Tfelt-Hansen P, Welch KMA (eds) The Headaches, 2nd ed. Philadelphia: Lippincott, Williams \& Wilkins, 2000, pp 731-740

20. Curran DA, Hinterberger $H$, Lance JW. Methysergide. Res Clin Stud Headache 1967; 1:74-122

21. Leone M, D'Amico D, Moschiano F, Fraschini F, Bussone G. Melatonin versus placebo in the prophylaxis of cluster headache: a double-blind pilot study with parallel groups. Cephalalgia 1996; 16:494-496

22. Jammes JL. The treatment of cluster headaches with prednisone. Dis Nerv Sys 1975; 36: 375-376

23. Rapoport AM, Bigal ME, Tepper SJ, Sheftell FD. Treatment of cluster headache with topiramate: effects and side-effects in five patients. Cephalalgia 2003; 23: 69-70

24. Anthony M. Arrest of attacks of cluster headache by local steroid injection of the occipital nerve. In: Rose FC (ed) Migraine: Clinical and Research Advances. London: Karger, 1985, 169-173

25. Ambrosini A, Vandenheede M, Rossi P, Aloj F, Sauli E, Buzzi $M G$, et al. Suboccipital (GON) injection with long-acting steroids in cluster headache: a double-blind placebo-controlled study. Cephalalgia 2003; 23: 734

26. Peres MFP, Stiles MA, Siow HC, Rozen TD, Young WB, Silberstein SD. Greater occipital nerve blockade for cluster headache. Cephalalgia 2002; 22: 520-522

27. Franzini A, Ferroli P, Leone M, Broggi G. Stimulation of the posterior hypothalamus for treatment of chronic intractable cluster headaches. The first reported series. Neurosurgery 2003; 52: 1095-1101
28. Leone M, Franzini A, Broggi G, Dodick D, Rapoport A, Goadsby PJ, et al. Deep brain stimulation for intractable chronic cluster headache: proposals for patient selection. Cephalalgia 2004; 24: 934-937

29. Weiner RL, Reed KL. Peripheral neurostimulation for control of intractable occipital neuralgia. Neuromodulation 1999; 2: $217-222$

30. Sjaastad O, Russell D, Horven I, Bunnaes U. Multiple neuralgiform unilateral headache attacks associated with conjunctival injection and appearing in clusters. A nosological problem. Proceedings of the Scandinavian Migraine Society. Arhus, 1978, 31

31. Sjaastad O, Saunte C, Salvesen R, Fredriksen TA, Seim A, Roe OD, et al. Shortlasting unilateral neuralgiform headache attacks with conjunctival injection, tearing, sweating, and rhinorrhea. Cephalalgia 1989; 9: 147-156

32. Dodick DW, Trentman T, Zimmerman R, Eross EJ. Ocipital nerve stimulation for intractable chronic primary headache disorders. Cephalalgia 2003; 23: 701

33. Raimondi E, Gardella L. SUNCT syndrome. Two cases in Argentina. Headache 1998; 38: 369-371

34. Matharu MS, Boes CJ, Goadsby PJ. SUNCT syndrome: prolonged attacks, refractoriness and response to topiramate. Neurology 2002; 58: 1307

35. Pareja JA, Joubert J, Sjaastad O. SUNCT syndrome. Atypical temporal patterns. Headache 1996; 36: 108-110

36. Pareja JA, Kruszewski P, Sjaastad O. SUNCT syndrome: trials of drugs and anesthetic blockades. Headache 1995; 35: 138-142

37. Matharu MS, Cohen AS, Goadsby PJ. SUNCT syndrome responsive to intravenous lidocaine. Cephalalgia 2004; 24: 985-992

38. Ertsey C, Bozsik G, Afra J, Jelencsik I. A case of SUNCT syndrome with neurovascular compression. Cephalalgia 2000; 20: 325

39. Peatfield R, Bahra A, Goadsby PJ. Trigeminal-autonomic cephalgias (TACs). Cephalalgia 1998; 18: 358-361

40. Leone M, Rigamonti A, Usai S, D’Amico D, Grazzi L, Bussone G. Two new SUNCT cases responsive to lamotrigine. Cephalalgia 2000; 20: 845-847

41. D'Andrea G, Granella F, Ghiotto N, Nappi G. Lamotrigine in the treatment of SUNCT syndrome. Neurology 2001; 57: 1723-1725

42. Gutierrez-Garcia JM. SUNCT syndrome responsive to lamotrigine. Headache 2002; 42: 823-825

43 Chakravarty A, Mukherjee A. SUNCT syndrome responsive to lamotrigine: documentation of the first Indian case. Cephalalgia 2003; 23: 474-475

44 Piovesan EJ, Siow C, Kowacs PA, Werneck LC. Influence of lamotrigine over the SUNCT syndrome: one patient follow-up for two years. Arq Neuropsiquiatr 2003; 61: 691-694

45 Graff-Radford SB. SUNCT syndrome responsive to gabapentin. Cephalalgia 2000; 20: 515-517

46 Porta-Etessam J, Martinez-Salio A, Berbel A, Benito-Leon J. Gabapentin (neurontin) in the treatment of SUNCT syndrome. Cephalalgia 2002; 22: 249

47 Hunt $\mathrm{CH}$, Dodick DW, Bosch P. SUNCT responsive to gabapentin. Headache 2002; 42: 525-526

48 Leone M, Franzini A, D’Andrea G, Broggi G, Casucci G, Bussone $G$. Deep brain stimulation to relieve drug-resistant SUNCT. Ann Neurol 2005; 57: 924-927 